\section{References: Publications of the Hirsch Institute of Tropical Medicine (up to 09/2018)}

\section{International peer-reviewed journals}

1. Nordmann T, Feldt T, Bosselmann M, Tufa TB, Lemma G, Holtfreter M, Häussinger D. Outbreak of Louse-Borne Relapsing Fever among Urban Dwellers in the Arsi Zone, Central Ethiopia, from July to November 2016. Am J Trop Med Hyg 2018; 98: 1599-1602.

2. Schönfeld A, Feldt T, Tufa TB, Orth HM, Fuchs A, Mesfun MG, Pfäfflin F, Nordmann T, Breuer M, Hampl M, Häussinger D.

Prevalence and Impact of Sexually Transmitted Infections in Pregnant Women in Central Ethiopia.

Int J STD AIDS 2017; 29: 251-258.

3. Pfäfflin F, Tufa TB, Getachew M, Nigussie T, Schönfeld A, Häussinger D, Feldt T, Schmidt N. Implementation of the WHO Multimodal Hand Hygiene Improvement Strategy in a University Hospital in Central Ethiopia.

Antimicrob Resist Infect Control 2017; 6: 3.

\section{International conferences (poster and oral presentations)}

4. Fuchs A, Hörner I, Beyene T, Nordmann T, Bosselmann M, Abdissa S, Hurissa Z, Orth HM, Schönfeld A, Kaasch A, Mackenzie C, Pfeffer K, Häussinger D, Feldt T.

Outcome of patients with sepsis in a teaching hospital in Central Ethiopia.

Oral presentation at the Congress for Infectious Diseases and Tropical Medicine (KIT), Cologne, Germany 2018.

5. Mesfun MG, Feldt T, Fuchs A, Nordmann $T$, Schönfeld A, Bosselmann M, Heyszl S, Kuffour EO, Häussinger D.

Efficacy of Helicobacter-pylori eradication therapy among HIV-positive and HIV-negative individuals in Central Ethiopia and effects on CD4 cell count and haemoglobin levels.

Poster presentation at the Congress for Infec- tious Diseases and Tropical Medicine (KIT), Cologne, Germany 2018.

6. Mesfun MG, Fuchs A, Holtfreter M, Feldt T, Häussinger D.

Cryptosporidiosis and other intestinal parasitic infections among diarrheal and non-diarrheal HIV-positive patients at Asella Teaching Hospital, Ethiopia.

Poster presentation at the Congress for Infectious Diseases and Tropical Medicine (KIT), Cologne, Germany 2018.

7. Tufa TB, Fuchs A, Schönfeld A, Nordmann T, Bosselmann M, Abdissa S, Hurissa Z, Orth HM, Kaasch A, MacKenzie C, Pfeffer K, Feldt T, Häussinger D.

Isolation of pathogenic microbes from patients with febrile illness and characterization of antibiotic resistance at Asella Teaching Hospital, Central Ethiopia.

Poster presentation at the Congress for Infectious Diseases and Tropical Medicine (KIT), Cologne, Germany 2018.

8. Mesfun MG, Pfäfflin F, Berhe N, Golassa L, Feldt $\mathrm{T}$, Häussinger D.

Declining trend of malaria and high efficacy of Artemether-Lumefantrine(Coartem ${ }^{\circledR}$ ) against $P$. falciparum in the Ziway Dugda district, Ethiopia. Poster presentation at the Annual Meeting of the German Society for Parasitology, Berlin, Germany 2018.

9. Mesfun MG, Fuchs A, Holtfreter M, Feldt T, Häussinger D.

Cryptosporidiosis and other intestinal parasitic infections among diarrheal and non-diarrheal HIV-positive patients at Asella Teaching Hospital, Ethiopia.

Poster presentation at the Annual Meeting of the German Society for Parasitology, Berlin, Germany 2018.

10. Sarfo FS, Castelnuovo B, Fanti I, Feldt T, Incardona F, Kaiser R, Lwanga I, Marrone G, Sönnerborg A, Tufa TB, Zazzi M, de Luca A.

Effectiveness of protease-inhibitor-based secondline antiretroviral therapy in sub-Saharan Africa. Oral presentation at the HIV resistance workshop in Johannesburg, South Africa, 2017. 
11. Tufa TB, Nordmann T, Bosselmann M, Schönfeld A, Fuchs A, Feldt T, Häussinger D.

Detecting TB cases among household contacts of patients with pulmonary TB through Active Contact Tracing in the Arsi Zone, Ethiopia.

Poster presentation at the ID Week, San Diego, USA, 2016.

12. Schönfeld A, Getachew M, Beyene T, Fuchs A, Pfäfflin F, Schmidt N, Feldt T, Häussinger D.

WHO multimodal hand hygiene improvement strategy and its effect on hand hygiene adherence at Asella Teaching Hospital, Central Ethiopia.

Poster presentation at the ID Week, New Orleans, USA, 2016.

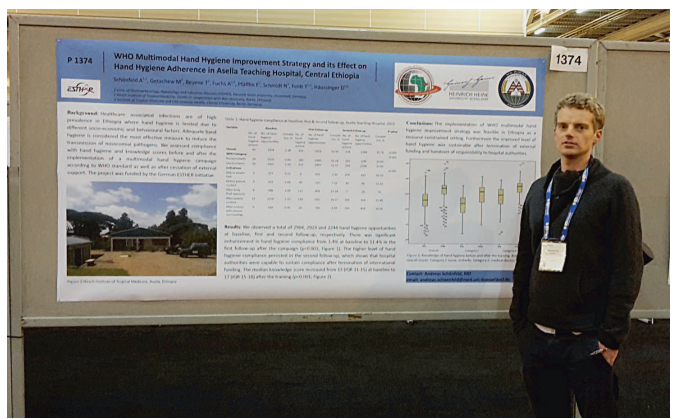

Poster presentation by Dr. Schönfeld during the "Infectious Diseases Week" in New Orleans, 2016

13. Fuchs A, Schönfeld A, Nordmann T, Tufa TB, Lema G, Pfäfflin F, Feldt T, Häussinger D.

Frühdetektion von Tuberkulose durch aktives Case Finding im ländlichen Äthiopien.

Oral and poster presentation at the Annual Meeting of the German Society of Tropical Medicine and International Health, Bonn, Germany, 2016.

14. Schönfeld A, Getachew M, Cirri L, Fuchs A, Orth HM, Häussinger D, Feldt T.

Intestinal parasitic infections among HIVinfected individuals in Asella, Central Ethiopia. Poster presentation at the Annual Meeting of the German Society of Tropical Medicine and International Health, Bonn, Germany, 2016.
15. Fuchs A, Cirri L, Schönfeld A, Orth HM, Beyene T, Feldt T, Häussinger D.

STIs and chronic hepatitis in pregnant women in Arsi, Central Ethiopia: prevalence, risk factors and effects on new-borns' health.

Oral and poster presentation at the Congress for Infectious Diseases and Tropical Medicine (KIT), Würzburg, Germany 2016.

16. Fuchs A, Cirri L, Schönfeld A, Mesfun MG, Orth HM, Breuer M, Holtfreter M, Feldt T, Häussinger D.

Low prevalence of intestinal parasitic infections among pregnant women in Arsi, Central Ethiopia. Poster presentation at the Congress for Infectious Diseases and Tropical Medicine (KIT), Würzburg, Germany 2016.

17. Orth HM, Cirri L, Schönfeld, A, Tufa TB, Fuchs A, Breuer M, Feldt T, Häussinger D.

High prevalence of chronic liver disease in Arsi, Central Ethiopia.

Poster presentation at the Congress for Infectious Diseases and Tropical Medicine (KIT), Würzburg, Germany 2016.

18. Orth HM, Cirri L, Schönfeld A, Hallu A, Riedel $\mathrm{F}$.

Severe neonatal chlamydial conjunctivitis with unilateral corneal perforation after unattended home delivery in rural Ethiopia.

Poster presentation at the Congress for Infectious Diseases and Tropical Medicine (KIT), Würzburg, Germany 2016.

19. Cirri L, Schönfeld A, Fuchs A, Tufa TB, Orth HM, Breuer M, Feldt T, Häussinger D.

Low prevalence of HIV in spite of high prevalence of STIs in pregnant women in the Arsi Zone, Central Ethiopia.

Oral presentation at the International Conference for Infectious Diseases (ICID), Hyderabad, India, 2016.

20. Cirri L, Schönfeld A, Tufa TB, Feldt T, Häussinger D.

Improving tuberculosis case finding through active contact tracing: a community-based crosssectional survey in Central Ethiopia.

Eur Respir J 2016; 48: Meeting Abstract PA2784. 
21. Mesfun MG, Pfäfflin F, Schmidt N, Schönfeld A, Cirri L, Nuguse T, Tufa TB, Feldt T, Häussinger D.

Enhancing hospital hygiene by implementing the WHO multimodal hand hygiene improvement strategy at Asella Teaching Hospital, Ethiopia. Poster presentation at the $13^{\text {th }}$ Congress for Hospital Hygiene, Berlin, Germany, 2016.

22. Fuchs A, Beyene T, Feldt T, Markwerth P, Gebregeorgis W, Getachew M, Pfäfflin F, Breuer M, Orth HM, Häussinger D.

Low prevalence of HIV-1 infection in pregnant women in the Arsi Region, Ethiopia despite high rates of other sexually transmitted infections.

Poster presentation at the German-Austrian AIDS conference (DÖAK), Düsseldorf, Germany, 2015.

23. Pfäfflin F, Schmidt N, Tufa TB, Feldt T.

Implementation of the WHO multimodal hand hygiene improvement strategy in selected wards of Asella Teaching Hospital, Ethiopia.

Poster presentation at the $3^{\text {rd }}$ International Conference on Prevention \& Infection Control (ICPIC), Geneva, Switzerland, 2015.

\section{Ethiopian conferences (poster and oral presentations)}

24. Nordmann T, Tufa TB, Fuchs A, Schönfeld A, Orth H, Bosselmann M, Feldt T.

The incidence of drug-induced liver injury among patients receiving anti-tuberculosis treatment in the Arsi Zone, Central Ethiopia.

Poster presentation at the TRAC Annual Conference, Addis Ababa, Ethiopia, 2017.

25. Tufa TB, Nordmann T, Bosselmann M, Schönfeld A, Fuchs A, Feldt T.

Detecting missing TB cases among household contacts of patients with pulmonary TB through active contact tracing in the Arsi Zone, Ethiopia. Oral and poster presentation at the TRAC Annual Conference, Addis Ababa, Ethiopia, 2017.

26. Nordmann T, Tufa TB, Bosselmann M, Feldt T. Treatment outcome among tuberculosis patients in the Arsi Zone between 2012-2014.
Oral presentation at the TRAC Annual Conference, Addis Ababa, Ethiopia, 2017.

27. Cirri L, Schönfeld A, Tufa TB, Häussinger D, Feldt T.

Improving tuberculosis case-finding through active contact tracing: a community-based crosssectional survey in Central Ethiopia.

Oral presentation at the TRAC Annual Conference, Dire Dawa, Ethiopia, 2016.

\section{Further Information}

Further information about the Institute can be found on the homepage of the HITM:

https://www.uniklinik-duesseldorf.de/en/ department-of-gastroenterology-hepatologyand-infectious-diseases/hirsch-institute-oftropical-medicine

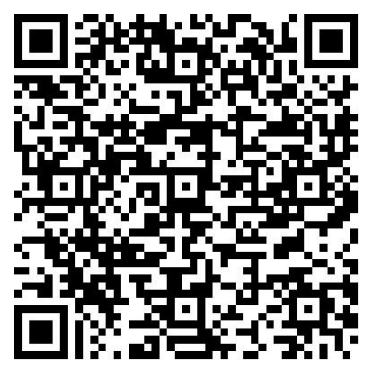

